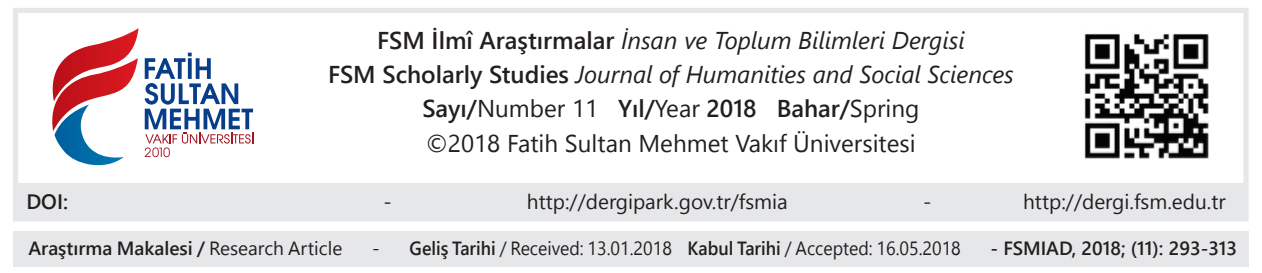

\title{
Kur'ân'ın Mana Zenginliği ve Fonetik Anlam Yansıması Üzerine Bazı Örneklemeler
}

Bahattin Dartma*

\section{Öz}

Kur'ân-1 Kerîm'in vecîz olan ifadeleri, çok geniş anlamlar içermektedir. Arap edebiyatının zirvede olduğu bir dönemde nâzil olmasına rağmen, bu zirveyi de aşmak suretiyle söz konusu alandaki eşsizliğini meydan okuyarak (tahaddî) ortaya koymuştur. İhtivâ ettiği sözleri, cümle yapısı ve sesleri ile onun bu üstünlüğü, hemen herkes tarafindan kabul edilmektedir.

Kur'ân'ı anlamak için hakkında sayısız denecek kadar inceleme ve araştırma yapılmıştır. Hatta ona dair yazılan bazı tefsirler onlarca ciltten müteşekkildir. Ancak yapılan bu çalışmalar daha ziyade onun literal anlamlarıyla ilgilidir.

Kanaatimize göre onun birtakım kelimelerinde yer alan bazı harflerin telaffuzu esnasında ortaya çıkan seslerin yansıttığı ilave anlamlar da söz konusudur.

İşte bu çalışmada, Kur'ân'ın bazı kelime ve harflerinin okunuşu sırasında çıan seslerin yansıttığı bu ek ve tali derecedeki manaların tespitine çalışlacaktır.

Anahtar Kelimeler: Quran, mana zenginliği, ses, fonetik anlam, anlam yansıması.

* Prof. Dr., Marmara Üniversitesi İlahiyat Fakültesi Tefsir Ana Bilim Dalı, İstanbul/Türkiye, bahagani@gmail.com, orcid.org/0000-0001-6577-0215 


\title{
Some Samples on Semantic Richness and Phonetical Meaning Reflections in the Qur'an
}

\begin{abstract}
The terse statements in the Holy Koran offer wide meanings. Although the Qur'an was revealed at a time of summit of the Arab literature, it has transcended this summit by defying its uniqueness in this field. It is clear by everybody that its sounds, words and sentence structure show its superiority.

To understand the Qur'an, countless research and investivations were conducted about it. Besides, some commentaries written about it are composed of dozens of volumes. Yet the results of these studies are rather related to its literal meaning.

In our humble opinion, additional meaning reflected during the pronunciation of some letters in some words also exist.

This small-scale study focusses on the above stated additional and secondary meanings reflected during the reading the Qur'anic words and the sounds.
\end{abstract}

Keywords: Qur'an, richness of meaning, , sound, phonetic meaning, meaning reflection. 


\section{Giriş}

Kur'ân-1 Kerîm, az sözle çok anlam ifade eden, zengin derin muhtevalara sahip olan bir şaheserdir (cevâmi 'u'l-kelim). Kur'ân'1n bu mümeyyiz hususiyeti bizzat Resûlullah (sav) tarafindan tam bir sarâhatle ifade edilmiştir:

"Düşmanın üzerine korku sal[1n]makla bana yardım edildi (ben muzaffer kılındım). Bana cevâmi 'u'l-kelim verildi. Ben uyurken yerin hazinelerinin anahtarları bana getirilerek ellerime kon[ul]du."'1

İşte buradaki “cevâmi ‘u’l-kelim”den maksat, Kur’ân-1 Kerîm’dir.

Kur'ân, Arap edebiyatının en üst düzeyde seyrettiği bir zaman diliminde inmesine rağmen bu alanda eşsizliğini ve erişilmezliğini, karşı konulmaz bir dirayet ve üslupla ortaya koymuştur. Onun bu yöndeki üstünlüğü, kendisine aşırı bir şekilde karşı olanlar ve husûmet besleyenler tarafından bile itiraf edilmiştir. Zira onun hemen her âyet veya kelimesi bir yana, bazen bir harekesi bile önemli incelikler ve nükteler ihtiva etmektedir. Hatta bazı harflerinin telaffuzu esnasında verdiği sesler dahi kayda değer hikmetlere işaret etmektedir. Bu münasebetle olmalı ki tarih boyunca hakkında, çeşitli açılardan pek çok inceleme ve araştırma yapılmış, -bazıları onlarca cilt tutan- çok sayıda tefsir yazılmıştır. Ve bundan sonra da bu tür çalışmalar devam edecektir. Çünkü Kur’ân-1 Kerîm, Yüce Allah tarafindan gönderilen ve ölümsüz değerlere kaynaklık eden en son ilâhî metindir. Bundan sonra vahiy gelmeyeceğine göre insanların, hidâyette olmayanlarının hidâyete gelmeleri, hidâyette olanlarının ise hidâyet üzere devam etmeleri için Kur'ân'a sarılmaktan başka çarelerinin olmadığı görülmektedir. Dolayısı ile Kur'ân'ın, insanlığın her iki dünyasında da yararına olacak tüm yönlerinin en ince ayrıntılarına kadar araştırılarak ortaya çıkarılması elzemdir.

İşte bu düşünceden hareketle biz de bu mütevâzî çalışmamızda, onun engin mana zenginliğine kısaca değindikten sonra, özellikle bazı harf ve kelimelerin telaffuzu esnasında ortaya çıkan seslerin ilave olarak yansıttıkları fonetik anlamları, bazı örnekler üzerinden tespite çalışacağı. ${ }^{2}$

1 Buhârî, Muhammed b. İsmâ‘̂il, Sahîhu'l-Buhârî, İstanbul, 1981, Cihâd, 122, Ta ‘bîr, 22, İ'tisâm, 1; Müslim, Ebû'l-Huseyn Müslim b. El-Haccâc, Sahîhu Müslim, İstanbul, 1981, Mesâcid, 7.

2 Burada şunu özellikle belirtmemiz gerekir ki bu çalışmamız, harflerin seslerini konu edinmektedir. Bu nedenle ilk bakışta bunun hurûfilikle bir ilgisinin olduğu zannedilebilir. Ancak etüdümüzün hurûfilikle hiçbir ilgisi yoktur. Bu nedenle burada hurûfilikle ilgili kısaca bilgi vermemiz gerekmektedir: Hurûfilik, harflerle sayıların kutsallığını kabul ederek bunlara çeşitli sembolik anlamlar yükleyen bir anlayıştır. Bu sistemde bütün kâinât, insanın yüzünde bulunduğu kabul edilen ve birine 'hutût-i ebiyye', diğerine de 'hutût-1 ümmiyye' denilen yedişer hatlı iki görünüşle açıklanır. Bütünüyle dini hükümler yirmi sekiz ve otuz iki sayısına uygula- 


\section{Kur'ân'ın Mana Zenginliği:}

Kur'ân'ın muhtevasının zengin olduğuna dair pek çok söz söylenmiş, çalışmalar yapılmıştır. Dolayısı ile meseleyi uzatmamak için bu hususa değinmeden misallere geçmeyi uygun gördük. Ancak konuya ilişkin örneklemelere geçmeden önce meselenin önemine dikkat çekmek amaciyla Kur'ân'ın bu özelliğine dair bir anekdotla işe başlamak istiyoruz:

Rivâyete göre Esmacî şöyle demiştir: "Ben bedevî bir câriyeyi şu beyitleri okurken işittim:

'Bütün günahlarım için Allah'tan mağfiret dilerim. Bana helal olmayan bir insanı öptüm. Ceylan gibi yumuşak bir nazlanması vardı. Gece yarı oldu ve ben (bu gecenin) namazını kılmadım.'

Ona dedim ki, Allah canını alsın, ne kadar da fasihsin! O şöyle dedi: Yüce Allah,

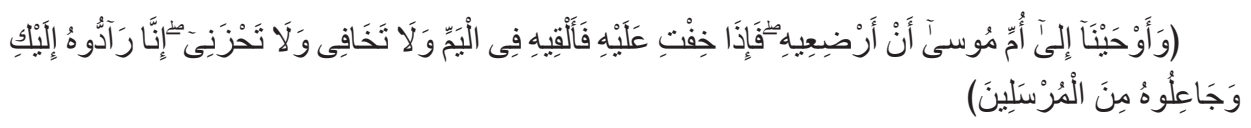

'Mûsâ'nın anasına, 'onu emzir, kendisine zarar geleceğinden endişelendiğinde onu denize (Nil nehrine) bırak, hiç korkup üzülme, çünkü biz onu sana geri vereceğiz ve onu peygamberlerden biri yapacağız' diye bildirdik”3 buyurduğun-

narak bu hükümlerin insanın yüzünde temsil edildiği ileri sürülür. Bu anlayışı benimseyenler, âyet ve hadisleri hurûfilik sistemi çerçevesinde bâtinî te'villere tabi tutmuşlardır. Hurûfîler, özellikle hurûf-1 mukattaanın müfessirlerce ileri sürüldügünün aksine müteşâbih değil, muhkem olduğunu savunmuşlar, sayısı on dördü bulan bu harfleri de insanın yüzündeki hatlarla ilişkilendirerek açıklamışlardır. Âyetleri, cennet, cehennem ve âhiret hallerini ve bütün dini hükümleri yirmi sekiz veya otuz iki harfe irca ederek te'vîle tabi tutarlar. Mesela kelime-i şehâdette geçen Allah lafzında beş harf vardır; bu harflerin adlarının yazımından on dört harf ortaya çıkar; yine kelime-i şehadetteki Muhammed lafzında da beş harf bulunmakta olup bunların imlası da on dört harfi verir; böylece ikisinin toplamı yirmi sekiz eder; buna kelime-i şehadetin ilk kelimesindeki dört harf eklendiğinde sayı otuz ikiye ulaşır. Şu halde kelime-i şehadet, Arap ve Fars alfabelerinin tamamını ve bunların içerdiği hurûfî anlamları ifade etmektedir. Mesela “ـُ "كُ" kelimesi hurûfilik sisteminde şöyle yorumlanır: Kelimeyi oluşturan iki harfin Arapça okunuşu (kâf ve nûn) esas alınır. Böylece altı harf ortaya çıkar (ك-ا-ف-ن-ون). Bu şekilde elde edilen altı sayısı altı yönü temsil eder; altı yön ise mekanın aslî özelliklerinden olduğuna göre Allah'ın "kün” emriyle oluşun ve âlemin (kevn ve mekan) nasıl meydana geldiği ifade edilmiş olur. Hurûfîlerin önemli bir kısmı, ölümden sonra hayat olmadığına, birleşik varlıkların tekrar basit hale dönüşeceğine, insanın hurûfîliğin esasını oluşturan otuz iki kelimenin bilincine varınca kendisinden yükümlülüklerin kalkacağına inanırlar.... Bkz., Aksu, Hüsamettin, "Hurûfilik", Diyanet İslâm Ansiklopedisi (DİA), İstanbul, 1998, XVIII, 408-409. Görüldüğü gibi bizim konumuzun hurûfilikle hiçbir ilgisi yoktur.

Kasas (28), 7. 
da, 'iki emir, iki yasak, iki haber ve iki müjde'yi bir âyette zikretmişken benim bu söylediklerim onun yanında fasih mi sayılır!?"4

“Bu âyetteki iki emir, 'çocuğu emzir ve denize bırak'; iki yasak, 'korkma ve üzülme'; iki haber, 'onu sana geri vereceğiz ve onu peygamberlerden biri yapacağız'; iki müjde ise, bu iki haberin zımnında olan 'Mûsâ'yı (yani küçük çocuğu) geri döndürme ve onu peygamberlerden biri k1lma'dır."

Kur'ân'ın fesâhatını, belâğatını, mana incelik ve zenginliğini gösteren bu anekdottan sonra şimdi misallere geçebiliriz.

\section{Misâl 1:}

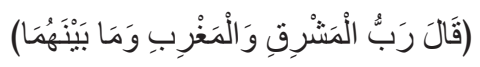

“O, doğunun, batının ve ikisinin arasında bulunanların Rabbidir."

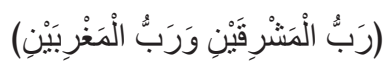

“(O,) iki doğunun ve iki batının Rabbidir".7

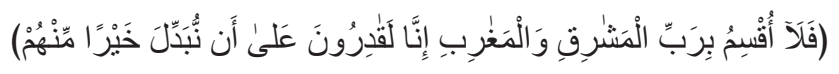

"Doğuların ve batıların Rabbine yemin ederim ki onların yerine onlardan daha iyilerini getirmeye bizim gücümüz yeter."

İlk âyette zikredilen "doğu”, bir gün[için]de güneşin doğduğu, "batı" da aynı gün gün[için]de güneşin battığı yöndür. Dar anlamda her bölgenin bir doğusu ve bir de batısı vardır. Çünkü "doğu" ve "batı" kelimeleri müfred (tekil) olarak kullanılmıştır.

İkinci âyette, Allah'ın iki doğunun ve iki batının Rabbi olduğu bildirilmektedir. Bunun şu anlama geldiği söylenebilir: Yer kürenin daima yarısı aydınlık, yarısı da karanlıktır. Karanlık olan kısmın doğusu ve batısı olmaz. Aydınlık olan kısmın ise bir doğusu ve bir de batısı olur. Yer küre tam olarak döndüğünde bu

4 Maverdî, Ebu'l-Hasen Ali b. Muhammed b. Habîb, en-Nüket ve'l- 'Uyûn, ta 'lîq, es-Seyyid b. Abdilmaqsûd b. Abdirrahîm, Dâru'l-Kütübi'l-İlmiyye - Mü'essesetü'l-Kütübi’s-Sekâfiyye, Beyrut, IV, 236; Ebû Hayyân, Muhammed b. Yusuf el-Bahru'l-Muhît, tahkik, Âdil Ahmed Abdulmevcûd - Ali Muhammed Mu'avvaz, 1. bask1, Dârul'l-Kütübi'l-İlmiyye, Beyrut, 1403/1993, VII, 100-101; Âlûsî, Ebu'l-Fazl Şihâbuddîn es-Seyyid Mahmûd, Rûhu'l-Me 'ânî fì Tefsîri'-Kur'âni'l- 'Azîm ve’s-Seb 'il-Mesânî, Dâru İhyâ'i’t-Türasi'l-Arabi, Beyrut, I, 32, XX, 45.

5 Vehbe ez-Zühaylî, et-Tefsîru'l-Münîr fi'l-'Akîdeti ve'ş-Şerî‘ati ve'l-Menheci, 10. bask1, Dâru'l-Fikr, Dımaşq, 1430/2009, X, 423.

6 Şu'arâ' (26), 28.

7 Rahmân (55), 17.

8 Me'âric (70), 40-41. 
defa karanlık olan kısım, güneşe karşı geldiği için aydınlanır, o zaman onun da bir doğusu ve bir batısı olmuş olur; aydınlık olan kısım ise karanlığa bürünür ve aynı şekilde kararan tarafın doğusu ve batısı olmaz. O halde yer kürenin -bir bütün olarak düşünüldüğü takdirde- iki doğusu ve iki de batısı vardır.

Asıl üzerinde durmak istediğimiz üçüncü âyette ise 'Yüce Allah'ın doğuların ve batıların Rabbi olduğu' haber verilmektedir. Bu âyetin de şu hususları anlattığı söylenebilir: Yeryüzünün pek çok bölgesi ve bu bölgelere ait pek çok da doğu ve batı vardır. Zaman farkı olacak şekilde, başka bir ifadeyle geniş anlamıyla ele alınırsa bir beldenin doğusu ve batısı, yıl boyu her gün hep aynı olmamaktadır. Bir beldeye doğan güneşin doğduğu yer, bir önceki gün doğduğu yerin aynısı değildir. Aynı şekilde güneşin battığı yer de böyledir. Her ne kadar yön aynı ise de her günün, hem doğuya ve hem batıya ait açısı birbirinden farklı olmaktadır. Yılın mevsimleri itibariyle güneşin doğuş ve batış yerleri devamlı değişmektedir. $\mathrm{Bu}$ ise ancak yer kürenin her yıl güneşin etrafinda dönmesiyle mümkündür. İşte yerin bu hareketi, her gün güneşin ayrı açılardan doğup yine ayrı açılardan batmasını gerektirmektedir. Hatta her gün, güneşin doğduğu ve battığı anlar birbirinden farklıdır. Meselâ Ramazan ayının her gününün imsak ve iftar vakitlerinin birbirinden farklı oluşu bundandır. Aynı şekilde yılın her gününün namaz vakitleri de böyledir. Yer kürenin, güneşin etrafinda dönüşüne göre bu vakitler sürekli olarak değişmektedir.

Güneşin doğduğu yerlerle battığı yerlerin her gün değişmesi, yer kürenin yuvarlak olduğunu da göstermektedir. Şayet yer düz olsaydı, güneşin her zaman aynı yerden doğması ve yine aynı yerden batması gerekirdi. O zaman da doğular ve batılar diye bir şey söz konusu olmazdı. Fakat yerin yuvarlak olması, hem kendi etrafında ve hem de güneşin çevresinde dönmesi, doğuların ve batıların varlığını gerektirmektedir. ${ }^{9}$

Görüldüğü gibi üç kelimeden oluşan "doğuların ve batıların Rabbi” ifadesi, coğrafya ve astronomi hakkında, her biri başlı başına birer araştırma konusu olabilecek mahiyette olan pek çok önemli ma'lûmâtı ihtiva etmektedir.

\section{Misâl 2:}

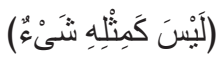

“O’nun (Allah'ın) hiçbir sûrette benzeri/dengi yoktur". ${ }^{10}$

9 es-Şa'ravi, Muhammed Mütevelli, Mu 'cizetü'l-Kur'ân, Ahbâru'l-Yevm, İdâretu'l-Kütübi ve'l-Mektebât, I, 23-25 (terceme, M. Sait Şimşek, Kur'ân Mucizesi, Konya, 1993, s. 35-38).

10 Şûrâ (42), 11. 


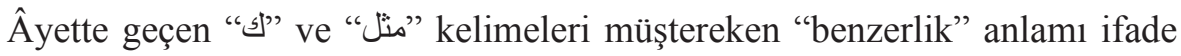

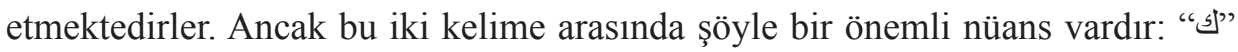
sıfatta, "مثل" ise zâtta "benzerlik" demektir." Buna göre âyetin anlamı şöyle olmalıdır: "Allah'ın ne zâtında, ne de sıfatlarında hiçbir benzeri/dengi yoktur."

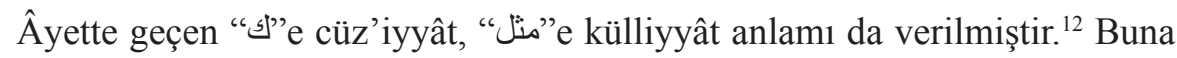
göre âyetin manas1, “Allah'ın ne cüz'iyyâtta, ne de külliyyâtta hiçbir benzeri/ dengi yoktur" şeklinde olmalıdır.

Bunların dışında bu iki kelimeye ("كثل"e), dolayısıyla âyete, "benzerlikte-zıdlıkta'; ${ }^{13}$ 'başlangıçta-sonda'; 'zâhirde-bâtında';14 'ğayb [görünmeyen] âlem[in]de-şehâdet [görünen] âlem[in]de'; ${ }^{15}$ 'cüz'iyyâtı-külliyyâtı bilmede'; ${ }^{16}$ 'dünyada-dünya dışında'; 'yerde-gökte'; 'yer altında-yer üstünde ve bunlar arasında'; '17 'selbî-sübûtî sıfatlarında hiç bir dengi yoktur' şeklinde manalar da yüklemek mümkündür.

Görüldüğ̈̈ gibi bu iki kelime, her birisi başlı başına birer çalışma konusu olan çok geniş ve derin manalar içermektedir.

11 Askerî, Ebû Hilâl, el-Fürûk el-Lüğaviyye, tahkîk ve ta'lîk, Muhammed İbrâhîm Selîm, Dâru'l-ìlm ve's-Sekâfeti, Qâhira, s. 156.

12 es-Safedî, Cemâluddîn Yûsuf b. Hilâl b. Ebi'l-Berekât, Keşfu'l-Esrâr ve Hetkü'l-Estâr, Nuru Osmaniye kütüphanesi, numara, 416, varak, 304ª

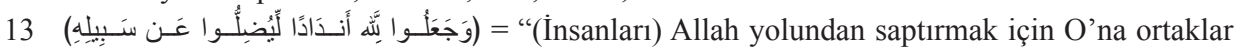
koştular” (İbrâhîm (14), 30). Konuya ilişkin başka âyetler için bkz., Bakara (2), 22, 165; Sebe' (34), 33; Zümer (39), 8; Fussilet (41), 9. Görüldüğü gibi gerek zikredilen bu âyette ve gerekse

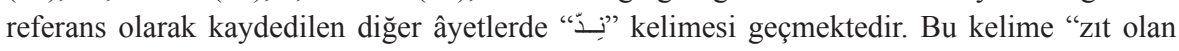
benzer/denk/ortak” anlamina gelmektedir. Bkz., el-Askerî, el-Fürûq, s. 154; Cezâ'irî, Nûruddîn b. Ni'metillah el-Huseynî el-Mûsevî, Fürûqu'l-Lüğât, tahqîq, Muhammed Razvânuddâye, Dımaşq, s. 213-214. Buna göre mezkûr âyetlerde 'Allah'a O'nun zıddı olan benzer/denk/ortak koşmalardan' bahsedilmektedir. Bu nedenle "benzerlikte-zıdlıkta denklik” ifadesini kullandık.

14 “O ilktir, sondur, zâhirdir, bâtındır. O, her şeyi bilendir” (Hadîd (57), 3).

15 “O, öyle Allah tır ki, O’ndan başka tanrı yoktur. Görülmeyeni ve görüleni bilendir. O, esirgeyendir, bağışlayandır" (Haşr (59), 22. Konuya ilişkin başka âyetler için meselâ bkz., En'âm (6), 73; Tevbe (9), 94, 105; R`ad (13), 9; Mü’minûn (23), 92; Secde (32), 6; Zümer (39), 46; Cum'a (62), 8; Teğâbün (64), 18.

16 "Ne yerde ne gökte zerre ă̆ırliğınca bir şey Rabbinden uzak (ve gizli) kalmaz. Bundan daha küçüğü ve daha büyüğü yoktur ki apaçık kitapta (levh-i mahfuzda) bulunmasın”" (Yûnus (10), 61; Sebe' (34), 3).

17 "Göklerde, yerde ve ikisi arasında bulunan şeyler ile toprağın altında olanlar hep O'nundur" (Tâhâ (20), 6) 


\section{Misâl 3:}

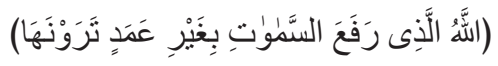

"Allah gökleri, gördüğünüz direkler olmaksızın yükseltmiştir."18

Kur'ân bu ifadeleriyle iki ayrı kanunun varlığını haber veriyor olabilir:

1. Yerçekimi kanunu.

2. Bu çekim kuvvetinin dışında kalan cisimlerin kendisiyle boşlukta durabilecekleri kanun. Nitekim dünyadaki diğer gök cisimleri uzayda, bir direk veya dayanak olmadan boşlukta durmaktadırlar.

Başka bir husus da şudur: Uzayda boşlukta belli kanunlara göre hareketini sürdüren her gök cismi, yani yıldız, gezegen vb. büyüklüğü oranında yerçekimi kuvvetine sahiptir. Meselâ güneşin hacmi, dünyanın 330.000, kütlesi ise 1.300.000 katıdır. Bu nedenle yerçekimi orada dünyaya oranla 27.9 kat daha fazladır. Ay ise, dünyadan çok küçük olduğu için yerçekimi dünyanınkinden altı kat azdır.

Güneşteki bu yerçekimi kuvveti, gezegenleri yörüngelerinde tutmaktadır ki, dünya da bu gezegenlere dâhildir. Böylece uzaya dağıtılan milyarlarca yıldız hep bu kanun uyarınca boşlukta durabilmekte ve aralarındaki yerçekimi kanunuyla birbirlerini belli yörüngede tutup -çarpışma olmadan- hareketlerini sağlamaktadırlar.

İşte gökteki cisimlerin biyolojik gözle görülebilen bir direk veya dayanak olmadan durmasının sebebinin bu çekim kanunu olduğunu ${ }^{19}$ söyleyebiliriz.

Görüldügü gibi kısa bir âyet, fizik ve astronomiye dair, her biri başlı başına birer araştırma konusu olan çok önemli hususları ihtiva etmektedir.

Yukarıda da belirtildiği gibi Kur’ân'ın 'cevâmi'u'l-kelim' yani, çok kısa ifadelere çok geniş anlamlar dercettiği konusu hemen herkesin kabulüdür. Dolayısı ile biz burada sözü edilen konuya dair bu üç misalle yetinip onun, ülkemizde üzerinde fazla durulmadığını gördüğümüz fonetik anlam yansıması üzerinde makalenin hacmine göre- biraz daha fazla misal vererek durmak istiyoruz.

\section{Kur'ân'ın kelime ve harflerinde fonetik anlam yansıması}

Bilindiği gibi Arapça'da harflerin kendilerine mahsus sıfatları, mahreçleri (çıkış yerleri) ve bu sıfat ve mahreçlere göre onların telaffuzu esnasında çıkardıkları çeşitli sesleri vardır. İşte Kur'ân'ın bazı kelimelerindeki bazı harflerin telaffuzu esnasında çıkardıkları bu seslerin bir takım ince fonetik anlamlar yansıttığını söylemek mümkündür. Ve kelimelerin lügat anlamlarına ilâveten ortaya

18 Ra'd (13), 2. Konuya dair başka bir âyet için meselâ bkz., Lokmân (31), 10.

19 Yıldırım, Celal, İlmin Işı̆̆ında Asrın Kur'ân Tefsiri, İstanbul, 1991, VI, 3023-3024. 
çıkan bu fonetik anlam yansımalarının, söz konusu lafızların ifade ettikleri sözlük anlamlarına daha bir hareketlilik, canlılık ve işlevsellik kazandırdıkları söylenebilir. Dolayısı ile Kur'ân'ın bu hususiyeti, “cevâmi ‘u'l-kelim” kapsamına giren bir özellik olarak kabul edilebilecek mahiyettedir denebilir.

İşte aşağıdaki misallerle Kur'ân'ın bu tür hususiyetlerini imkânlarımız ölçüsünde ortaya koymaya çalışacağız. Ancak yukarıda olduğu gibi burada da misallere geçmeden önce meselenin önemini vurgulamak için ilginç olduğunu tahmin ettiğimiz bir anekdotla konuya başlamak istiyoruz. Muhammed Hamîdullah konuyla ilgili olarak şöyle bir olay nakletmektedir:

“İstanbul'da iken bana Avrupalı bir müzik profesörü geldi ve şunları anlattı:

Kur'ân'1 tetkik ediyorum. Kur'ân şiir değil, fakat onda öyle bir musiki var ki, insanı hayrete düşürüyor. Şiirde bir kelimenin yerini değiştirsen vezin bozulur, musiki ve ahengin kaybolduğu derhal anlaşılır. Ancak, nesirden bir harf veya birkaç kelime kaldırsan ahenk bozulmaz. Çünkü onda ölçü yoktur. Kur'ân, şiir olmadığ 1 halde ondan bir harf kaldırsan derhal kendine has musikinin aksadığ görülür. Bu, beşer sözünde olamaz. Beşer sözünde böyle istisnasız tam bir ahenk bulunamaz. Bunun için Müslüman oldum. Yoksa ben Arapça bilmem. Kur'ân'ın manasinı da anlamam.

Bir zaman sonra bu profesör tekrar bana geldi ve dedi ki:

Ben, Kur'ân'daki musikinin, Kur'ân'ın bir mu 'cizesi olduğuna delalet ettiği

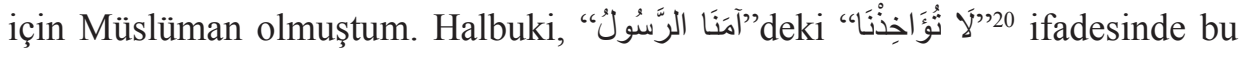
ahenk bozuluyor, musiki kalmıyor. Bir kelimede dahi bu ahengin bozulması onun mu'cizeliğini kaldırır, imanım sarsıldı.

Ona, oku bakalım, nasıl bozuluyor? dedim. Okudu ama, "و"1 med harfi gibi

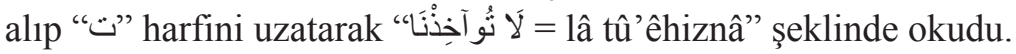

Ona dedim ki:

Sen yanlış okuyorsun. Oradaki “ 9 ", hemzenin yazılması için konmuştur, med

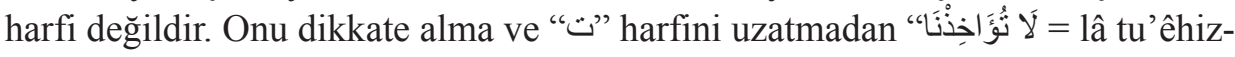
nâ" şeklinde oku.

Profesör, o halde tamam, musiki mükemmel dedi ve gitti.

Geçenlerde bana bir mektup yazmış, 'teşekkür ederim, imanımı tazeledin' diyordu. $" 21$

20 Bakara (2), 285-286.

21 Ateş, Süleyman, İslâm 'a İtirazlar ve Kur'ân-ı Kerîm'den Cevaplar, 4. bask1, Ankara, s. 201202. 
Bu dikkate değer anekdottan sonra şimdi konunun misallerine geçebiliriz.

\section{Misâl 1:}

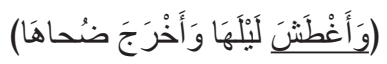

"Gecesini karartt1, gündüzünü ağarttı”.22

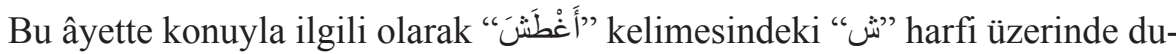
racağız.

“ش” harfinin hems, rihvet, tefeşşî, infitâh, istifâle, terkîk, zuhûr ve 1smât s1fatları vardir.

Şimdi konunun daha iyi anlaşılması için bu sıfatları kısaca açıklayalım:

Hems, lügatte sesi gizli çıkarmaya; tecvid ıstılahında ise bu sıfata sahip olan harfler telaffuz edilirken nefesin harflerle beraber akmasına denir. Sözü edilen harflerin telaffuzu esnasinda ses gizli ve zayıf olur.

Rıhvet, kelime olarak yumuşak olmak, 1stılahta ise kendilerinde bu sıfatın bulunduğu harflerin sükun ile telaffuzu esnasında ses ve nefesin beraberce akması demektir.

Tefeşşî, lügatta 'yayılmak', 1stılahta ise, 'tefeşşî sıfatı olan “ش” harfini telaffuz ederken sesin, dil ile damak arasında yayılmasına' denir.

İnfitâh, lügatta açılmak, ayrılmak manalarına gelir. Tecvid 1stılahında kendilerinde infitâh sıfatı bulunan harfler telaffuz edilirken dil ile yukarı damak arasının ayrılması manasinı ifade etmektedir.

İstifâle, lügatte aşağı olmak, alçalmak demektir. Istılahta ise istifâle harflerini telaffuz ederken dilin yukarı yükselmeyip ağzın dibinde kalması demektir.

Terkîk, lügatte inceltmek, zayıflatmak manalarını ifade eder. Tecvid ıstılahında bu sıfata sahip olan harfi okurken dilin kökünü üst çeneye kaldırmadan aşağ1da tutup harfin zatına bir incelik gelmesi, harfin sesiyle ağız içinin dolmaması ve neticede harfin incelmesidir.

Ismât, lügatte men etmek anlamınadır. Bu sıfata sahip olan harfler ağırdır. ${ }^{23}$

İşte söz konusu “" أَغْطَشَ" kelimesinin, harfleri arasında yer alan "ش” harfinin sahip olduğu 'hems' ve 'tefeşş̂ি’ sıfatları nedeniyle, lügat anlamının yanı sıra 'ka-

22 Nâizcât (79), 19.

23 Karaçam, İsmail, Kur'ân-ı Kerîm'in Faziletleri ve Okuma Kaideleri, Marmara Üniversitesi İlahiyat Fakültesi Yayınları (nu. 7), İstanbul, s. 218, 220, 224, 226, 227, 235, 244, 248; Ğânim Kaddûrî el-Hamed, el-Medhal ilâ İlmi Esvâti'l-Arabiyye, 1. bask1, Dâru Ammâr, Ammân, 1425/2004, s. 101, 107, 114, 130, 209, 255. 
ranlığın, sessiz ve 1ssız bir şekilde yavaş yavaş yayılıp çöktügü̆’ anlamını da yan-

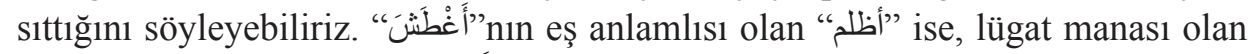
"kararttı” anlamı dışında “" "غَطَ"nın ifade ettiği bu hususları ihtiva etmemektedir. ${ }^{24}$

Şu âyetlerde de aynı hususun olduğunu söylemek mümkündür:

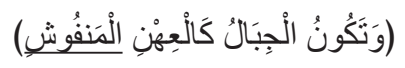

*“"Dağların da didilmiş renkli yün gibi olduğu gündür (o kâri'a!)." ${ }^{25}$

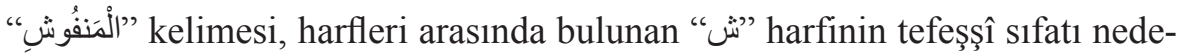
niyle 'dağların, didilmiş/parça parça olmuş renkli yünün her tarafa yayılması gibi dağıldığına' işaret etmektedir diyebiliriz.

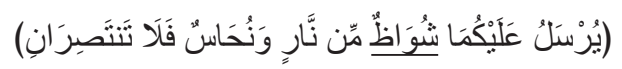

* “Üzerinize ateşten alev ve duman gönderilir de birbirinizi kurtaramaz ve yardımlaşamazsınız." 26

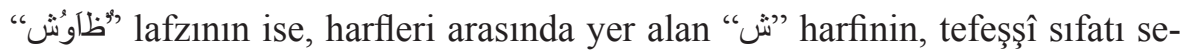
bebiyle, 'alevin her tarafa yayıldığına', ayrıca "b” harfinin sahip olduğu cehr, rihvet, 1tbâk, isti'lâ, tefhîm, zuhûr ve 1smât sıfatlar $1^{27}$ nedeniyle 'bu alevin çok şiddetli olduğuna' işaret ettiğini söyleyebiliriz.

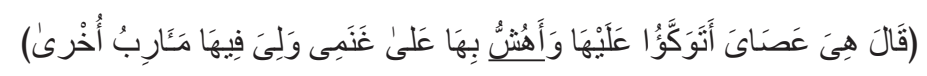

*"O, benim asamdır, dedi, ona dayanırım, onunla davarlarıma yaprak silkelerim; benim ona başkaca ihtiyaçlarım da vardır." ${ }^{\text {28 }}$

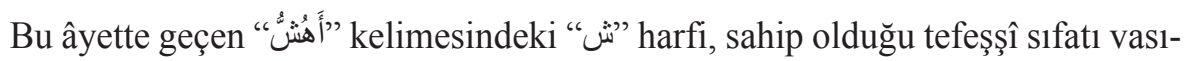
tasıyla telaffuz edilirken çıkan hışırtılı sesle, ağaç yaprakları düşerken çıkan hışırtı sesi birbirine çok benzemektedir. Dolayısı ile söz konusu " أَ zu esnasında çıkan bu hışırtılı ses, ağaç yapraklarının silkelenip yere düşerken 'çok hışırtı çıkardıkları' şeklinde ek bir anlam ifade ettiğini söylemek mümkündür.

\section{Misâl 2:}

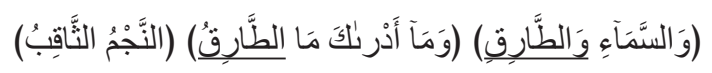

24 Mustafa Müslim, Mebâhis fì I'câzi'l-Kur'ân, Dâru'l-Menâra, 1. bask1, Cidde-Su'ûdiyye, 1408/1988, s. 130 .

25 Kâri‘a (101), 5.

26 Rahmân (55), 35.

27 Karaçam, Kur'ân-ı Kerîm 'in Faziletleri, s. 248. Bu sıfatların bir kısmı yukarıda, bir kısmı da aşağıda kısaca açıklandığı için burada tekrar izah edilmemişlerdir.

28 Tâhâ (20), 18. 
"Göğe ve târıqa andolsun. Târıqın ne olduğunu sen nereden bileceksin? (O karanlığı) delen yıldızdır."29

Bu âyetlerde de "طارق" kelimesini ele alacağız.

Söz konusu kelimeyi oluşturan “ر” kuvvetli, “ط” ve "ق̋" en kuvvetli harfler-

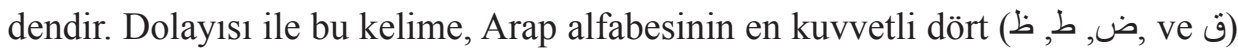
harfinden ${ }^{30}$ ikisi $($ (ط, ق) ile orta kuvvette olan “ $ر$ ”y bünyesinde bulundurmaktadır. " $\jmath$ " da kuvvetli harflerden biri olduğuna göre bu, kelimenin çok kuvvetli olduğu anlamını ifade edebilir.

“ط”nın, cehr, şiddet, qalqale, 1tbâq, isticlâ tefhîm, zuhûr ve 1smât; “ق””in cehr, şiddet, qalqale, infitâh, isticlâ, tefhîm, zuhûr ve ısmât; “j”nın, tekrîr, cehr, beyniyye, infitâh, istifâle, terkîk, zuhur, izlâq sıfatları vardır.

Şimdi konunun daha iyi anlaşılması için bu sıfatların yukarıda izah edilenlerin dışında kalanlarını kısaca açıklayalım:

Cehr, lügatta açıklamak, ortaya çıkarmak, söz söylerken sesi yükseltmeye, tecvid ıstılahında, kendisinde bu sifatın bulunduğu harfleri harekeli olarak telaffuz ederken nefes cereyanın hapsedilmesine denir.

Şiddet, lügatta kuvvet ve kudret anlamlarına gelir; tecvidde, bu sıfata ait harfler sükun ile okunduğu zaman sesin ve nefesin akmaması demektir.

Kalkale, lügatta hareket etmek ve ızdırâb manalarına gelir; tecvid ilminde ise, kuvvetli bir ses işitilinceye kadar mahrecin kılmılda[n]masına denir. Kalkale harflerinde hem cehr ve hem de şiddet sıfatı birlikte bulunmaktadır. Bundan dolayı bu harfler sükun ile okunurken ses ve nefes tamamen kesilir. Çünkü şiddet sıfatı sesin, cehr sıfatı da nefesin kesilmesini gerektirir. Bu harfler sâkin olarak okunduklarında sesleri tamamen kesileceğinden, zâtları ortaya çıkamayacağı için, bunların ortaya çıkması, mahreçlerinde hapsedilen sesin kuvvetli bir şekilde zuhuruyla mümkündür.

Itbâk, lügatta yapışmak, uyuşmak manalarına gelir; tecvid ıstılahında, dil kökünün ve ortasının yukarı damağa yükselmesiyle birlikte damağın dil ortası üzerine intibak etmesidir.

İsti 'lâ, lügatta yükselmek demektir; tecvid ıstılahında, isti'lâ sıfatlı harfleri telaffuz ederken dilin kökü ile birlikte üst damağa yükselmesine denir.

Tefhîm, lügatta bir şeyi büyüklemek ve kalın yapmak; tecvidde ise bu sıfata sahip olan harfler okunurken dilin kökünün üst damağa kalkması sebebiyle harfe bir kalınlık gelmesi ve ağzın içinin ses ile dolması demektir.

29 Târık (86), 1-3.

30 Karaçam, Kur'ân-ı Kerîm 'in Faziletleri, s. 215. 
Tekrîr, lügatta bir şeyi tekrar etmeye denir. Istılahta, tekrîr sıfatı olan " "yı okurken dil ucunun titremesi anlamını ifade eder.

Beyniyye, lügatta ortada olmak demektir. Istılahta, beyniyye harflerini telaffuz ederken sesin ne tamamen akması ne de tamamen hapsolmasina denir.

İzlâk, lügatta süratli ve kolay olmak demektir. Istılahta ise kendisinde bu sıfat bulunan harfleri telaffuz ederken dilin çabuk olması manasına gelir. ${ }^{31}$

Görüldüğ̈̈ gibi “ط” ve "ق" harflerinin sıfatları da onların en kuvvetli harfler olduğunu göstermektedir.

"Ses işitilecek şekilde kapıyı çalmak, dövmek, metal vb. şeyleri çekiçlemek/ çekiçle dövmek" gibi anlamlara gelen "طرق"dan türeyen bir kelime (ism-i fâil) olarak "طارق", döven, tokmak vurur gibi şiddetle vuran, geceleyin gelen, kap1 çalan, yürek hoplatan, sabaha karşı doğan sabah yıldızı" gibi manalar ifade etmektedir. ${ }^{32}$

Âyette kısaca şöyle bir teşbihin olduğu söylenebilir: Kendisine yemin edilen gökten maksat, câhiliyye/şirk karanlığ̣; “" “tan maksat da bu karanlığı bertaraf ederek tevhîd akîdesini yerleştirmek ve îmân nurunu parlatmak için peygam-

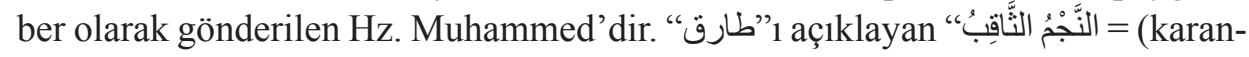
lığı) delen yıldız" ifadelerinin de bu teşbihi desteklediği söylenebilir.

Arapça'da yıldız anlamına gelen daha başka kelimeler de bulunmaktadır. Ancak bunlar arasında bu kelimenin kullanılmasının manidar bir hikmeti olmalıdır. Yukarıda da belirtildiği gibi "طارق", Arap alfabesinin en kuvvetli dört harfinin ikisi (ط, ق( ) ile kuvvetli bir ( ) harfini bünyesinde bulundurmakta, dolayısı ile en kuvvetli sıfatlara sahip görünmektedir. O halde, söz konusu kelime, ifade ettiği lügat ve 1stılah anlamlarının yanı sıra, kendisini oluşturan harflerin sahip olduğu sıfatların ve çıkardığı seslerin, "Resûlullah'ın çok güçlü bir şekilde gelip câhiliyye/şirk karanlığını, vahiy/îman nuruyla tamamen yok edeceği”" şeklinde ilave anlamlar ihtiva etmektedir diyebiliriz.

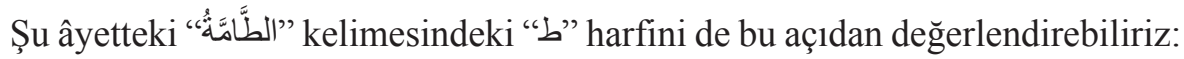

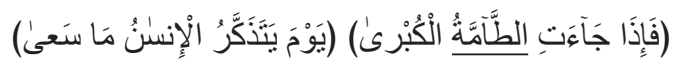

31 Karaçam, Kur'ân-ı Kerîm 'in Faziletleri, s. 218, 219, 222, 223, 225-226, 227, 229, 234, 242, 248, 249; Ğânim Kaddûrî el-Hamed, İlmu Esvâti'l-Arabiyye, s. 101, 107, 114, 118, 128, 131, 209, 210, 255.

32 el-Halîl b. Ahmed, Ebû Abdirrahmân el-Ferâhîdî, Kitâbu'l- 'Ayn, (tahqî̀, Mehdî el-Mahzûmî, İbrâhîm es-Sâmirâ'̂̂), Beyrut, 1988, V, 96-99 (T-R-Q mad.); İbn Manzûr, Muhammed b. Mükerrem b. 'Alî b. Ahmed el-Ensârî, Lisânu'l- 'Arab, Dâru Sâdır, Beyrut, 1990/1410, X, 215-218 (T-R-Q mad.); Yazır, Hamdi, Hak Dini Kur'ân Dili, İstanbul, VIII, 5699; es-Şa 'ravi, Mu 'cizetü'l-Kur'ân, III, 13-14 (terceme, M. Sait Şimşek, Kur'ân Mucizesi, s. 387). 
"Her şeyi alt üst eden o kıyâmet (büyük felâket) geldiği vakit, o gün insan yapıp ettiklerini hatırlar." 33

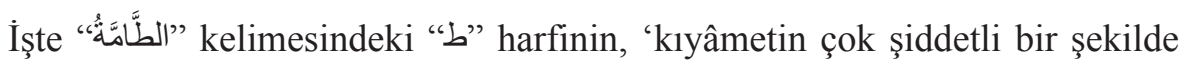
yıkıcı olacağı' anlamını da yansıttığını söylemek mümkündür.

\section{Misâl 3:}

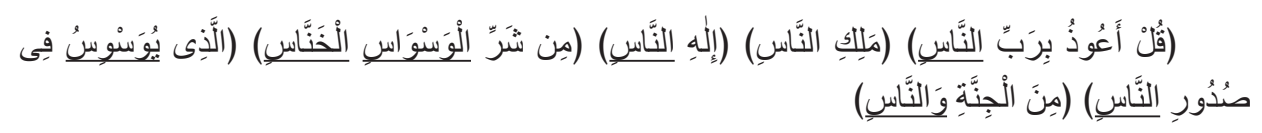

"De ki: Sığınırım ben insanların Rabbine, insanların Melikine (mutlak sahip ve hâkimine), insanların İlâhına, o sinsi vesvesenin şerrinden: O ki insanların göğüslerine (kötü düşünceler) fisıldar. Gerek cinlerden, gerek insanlardan (olan bütün vesvesecilerin) şerrinden Allah'a sığınırım!" 34

$\mathrm{Bu}$ âyetlerde ise on defa tekrar edilen ve sûrenin hemen hemen tamamında hâkim unsur olarak görülen "w" harfi ele alınacaktır.

Bu harfin, hems, rihvet, safîr, infitâh, istifâle, terkîk, zuhûr ve 1smât sıfatları vardir.

Şimdi konunun daha iyi anlaşılması için burada da mezkûr sıfatlardan yukarıda açıklananlar dışındakileri kısaca îzâh edelim:

Safîr, lügatte 1slık ve kuş sesine, 1stılahta ise bu sıfata mensup olan harfleri okurken kuvvetli ve keskin bir sesin çıkmasına denir. ${ }^{35}$

İşte surede hâkim unsur olan "w" harfinin sıfatları, özellikle de 'hems' sıfatı dikkate alındığında söz konusu harfin yer aldığı kelimelerin, ifade ettikleri kelime ve 1stılâhî manaların yanı sıra, "şeytan ve insanlardan olan vesvesecilerin, vesveselerini çok sessiz ve gizli olarak verdikleri”" şeklinde ek manalar yansıttı̆̆ını söylemek mümkündür.

Konu "w" harfinden açılmışken şu âyetleri de buna misâl olarak vermek mümkündür:

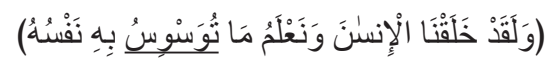

*“Andolsun, insanı biz yarattık ve nefsinin kendisine fisıldadıklarını biliriz." ${ }^{36}$

33 Nâzi'ât (79), 34-35.

34 Nâs (114), 1-6.

35 Karaçam, Kur'ân-ı Kerîm 'in Faziletleri, s. 228; Ğânim Kaddûrî el-Hamed, İlmu Esvâti'l-Arabiyye, s. 122.

36 Kâf (50), 16. 


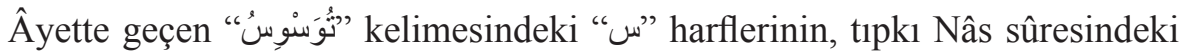
“س” harfleri gibi "nefsin, vesvesesini çok sessiz ve gizli olarak verdiğị” şeklinde ek anlam yansıttığını söyleyebiliriz.

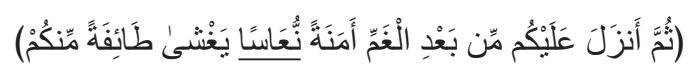

*“Sonra o kederin arkasından Allah size bir güven, bir kısmınızı bürüyen hafif bir uyku indirdi." 37

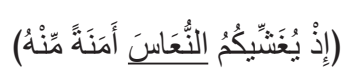

*“O zaman sizi, Allah’tan bir güven olmak üzere hafif bir uyku bürüyordu." ${ }^{38}$

Bu âyetlerde geçen "نُعَاس” kelimelerindeki " w” harflerinin de yine Nâs sûresindeki " " " harfleri gibi, bulundukları kelimelerin lüğavî anlamlarına ek manalar kattığını söyleyebiliriz. Dolayısı ile mezkur âyetlerdeki "w” harflerinin, "uykunun, sessiz bir şekilde yavaş yavaş onların üzerine çöktüğü" şeklinde ilâve anlamlar yansıttığını söylemek mümkündür. ${ }^{39}$

\section{Misâl 4:}

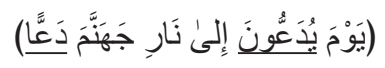

“O gün cehennem ateşine şiddetli bir şekilde itilip kak1lırlar."

Bu âyette “" "دَعَّاَ" kelimelerini ele alacağı.

Bu kelimelerdeki " $\varepsilon$ " harfinin, cehr, beyniyye, infitâh, istifâle, terkîk, zuhûr ve 1smât sıfatları vardır. ${ }^{41}$ Bu kelimelerin kökü olan "دَّ", 'sırt kısmından sert bir şekilde itilip kakılarak bir yere atılmak' anlamına gelmektedir. ${ }^{42}$

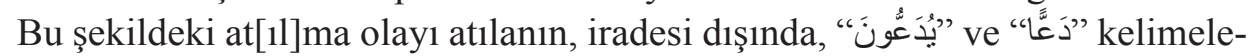
rindeki sâkin olan " $\varepsilon$ " harfinin çıkardığı sese benzer bir ses çıkartmasına sebep olmaktadır. ${ }^{43}$

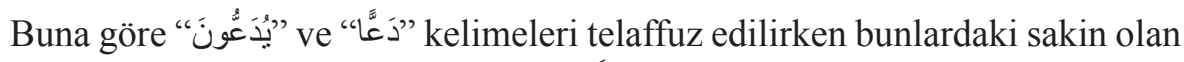

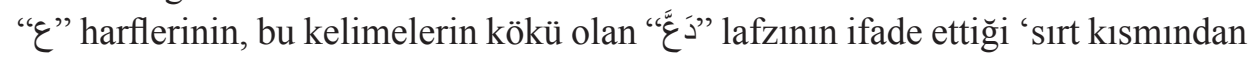

37 Âl-i İmrân (3), 154.

38 Enfâl (8), 11.

39 Kutub, Seyyid, et-Tasvîru'l-Fenniyyu fi 'l-Qur'ân, Dâru'ş-Şurûq, 6. bask1, 1400/1980 - 7. bask1, 1402/1982, Beyrut - Kâhire, s. 94-95.

40 Tûr (52), 13.

41 Karaçam, Kur'ân-ı Kerîm 'in Faziletleri, s. 248. Bu sıfatlar yukarıda kısaca îzâh edildiği için burada tekrar açıklanmamışlardır.

42 İbn Manzûr, Lisânu'l- 'Arab, VIII, 85, (D-A-A mad.).

43 Kutub, et-Tasvîru'l-Fenniyyu fi'l-Qur'ân, s. 95. 
sert bir şekilde itilip kakılarak bir yere atılma' şeklindeki sözlük anlamına ilâveten, atılanın atılırken gayr-i iradî olarak çıkarmış olduğu sese benzeyen kuvvetli bir ses çıkardığı' anlamını da yansıttı̆̆ını söylemek mümkün gibi görünmektedir.

\section{Misâl 5:}

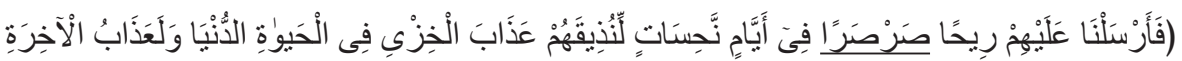

"Bundan dolayı biz de onlara dünya hayatında zillet azâbını tattırmak için o uğursuz günlerde soğuk bir rüzgâr gönderdik. Âhiret azabı elbette daha çok rüsvay edicidir." ${ }^{44}$

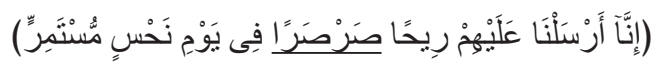

"Biz onların üstüne, uğursuzluğu devamlı bir günde dondurucu bir rüzgâr gönderdik"45

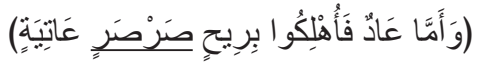

"Âd kavmi ise, uğultulu, kasıp kavuran bir firtına ile mahvedildiler". ${ }^{4}$

Bu âyetlerde de " "صرصر" kelimelerinde bulunan "ص" ve "ر” harfleri üzerinde duracağız.

"ص" harfinin, hems, rihvet, safîr, 1tbâk, isti 'lâ, tefhîm, zuhûr ve 1smât; "j" harfinin de tekrîr, cehr, beyniyye, infitâh, istifâle, terkîk, zuhur ve izlâk sıfatları vardir. ${ }^{47}$

“" kelimesi sözlükte, 'şiddetli soğuk' anlamına gelmektedir."

Söz konusu kelimenin, sözlük manasının yanı sıra, yapısını oluşturan ve safîr sıfatına sahip olan iki adet “ص” harfi ile, 'tekrîr' sıfatı bulunan ve yine iki adet olan " $\jmath$ " harfinin çıkardığı seslerin, bu 'aşırı soğuk rüzgara', 'sesli ve sürekli olan' anlamı ilave ettiğini ve buna göre mananın, 'son derece uğultulu ve gürültülü bir şekilde hiç ara vermeden devamlı olarak esen dondurucu bir soğuk rüzgar' şeklinde olabileceğini söylemek mümkündür.

44 Fussilet (41), 16.

45 Kamer (54), 19.

46 Hâkka $(69,6$.

47 Karaçam, Kur'ân-ı Kerîm 'in Faziletleri, s. 248. Bu sıfatlar yukarıda kısaca îzâh edildiği için burada tekrar açıklanmamışlardır.

48 İbn Manzûr, Lisânu'l-'Arab, IV, 450 (S-R-R mad.); ez-Zebîdî, Muhibbuddîn Ebû'l-Fayz es-Seyyid Muhammed Murtaza, Tâcu'l- 'Arûs, tahqîq Mustafa el-Hicâzî, 1393/1973, Kuveyt, XII, 301 (S-R-R mad.). 


\section{Misâl 6:}

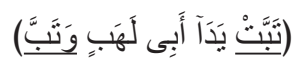

"Ebû Leheb’in iki eli kurusun! Kurudu da."49

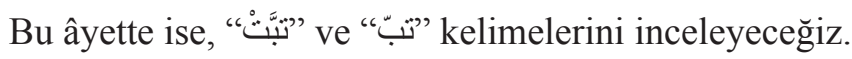

Bu kelimeleri meydana getiren "ت” harfinin hems, şiddet, infitâh, istifâle, terkîk ve 1smât; "ب" harfinin de cehr, şiddet, kalkale, infitâh, istifâle, terkîk, zuhûr ve izlâq sıfatları vardır. ${ }^{50}$

Kelimeleri oluşturan harflerin ortaya çıkardıkları seslerin, Ebû Leheb'e uygulanacak cezanın şiddetini gösterdiğ $i^{51}$ söylenebilir. Çünkü bu harflerde bulunan cehr, şiddet ve qalqale sıfatları çok sert bir ses ortaya koymaktadırlar.

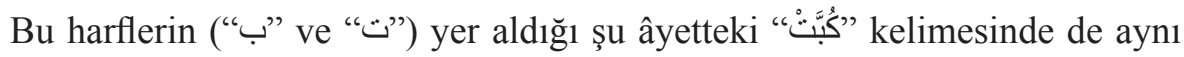
durumun söz konusu olduğunu söylemek mümkündür:

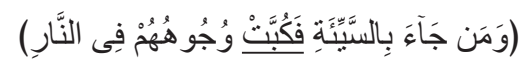

“(Rablerinin huzuruna) kötülükle gelen kimseler ise yüzükoyun cehenneme at1lirlar." 52

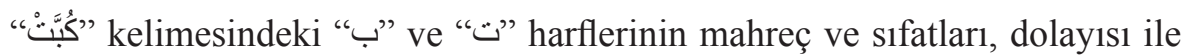
telaffuz edilirken çıkardıkları sesler, onların cehenneme çok sert ve şiddetli bir şekilde atıldıklarını ifade ettiği söylenebilir.

\section{Misal 7:}

$$
\text { (فَكُبْكُبْو ا فِيهَا هُمْ وَالْغَاوْنَ) }
$$

"Onlar ve azginlar oraya (cehenneme) tepetaklak atılırlar." 53

Bu âyette "كُكُبْكيُو "kelimesini inceleyeceğiz.

Kelimede yer alan "ب" harfinin sıfatları yukarıda izah edilmişti. "ك" harfinin ise hems, şiddet, infitâh, istifâle, terkîk, zuhûr ve ismât sıfatları vardır. ${ }^{54}$

49 Tebbet (111), 1.

50 Karaçam, Kur'ân-ı Kerîm 'in Faziletleri, s. 248. Bu sıfatlar yukarıda kısaca îzâh edildiği için burada tekrar açıklanmamışlardır.

51 Muhammed Huseyn Ali es-Sağîr, es-Savtu'l-Lüğavî fi'l-Kur'ân, 1. bask1, Dâru'l-Mü'errihi'l-Arabî, Beyrut, 1420/2000, s. 159; Tetik, Necati, “Ses ve Anlam İlişkisi Bakımından Kur'ân ve Kirâat”, Kur'ân ve Dil (Dilbilim ve Hermenötik) Sempozyumu, Van, 17-18 May1s, 2001, s. 298.

$52 \mathrm{Neml}(26), 90$.

53 Şu'arâ' (26), 94.

54 Karaçam, Kur'ân-ı Kerîm'in Faziletleri, s. 249. Bu sıfatlar yukarıda kısaca açıklandığı için burada tekrar îzâh edilmeyeceklerdir. 


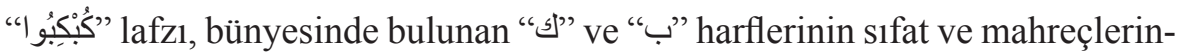
den, özellikle de "ب" harfindeki kalkaleden dolayı telaffuz edilirken " كُبكَ" güp" şeklinde şiddetli bir ses çıkmaktadır.

Güp, çarpma, atma, vurma, düşme ve benzeri hareketleri anlatan köktür. ${ }^{55}$ 'Kalbim güp güp atıyor,' 'yüreğim güp güp ediyor', 'güp diye düştü', 'güp güp vurmak' gibi cümlelerde bu kelime bazen tek bazen de çift olarak kullanılmaktadır. Tabir câizse, içi kum vb. maddelerle dolu olan bir çuval, yüksek bir yerden aşağı atılıp zemine düşünce de "güp" sesi duyulur.

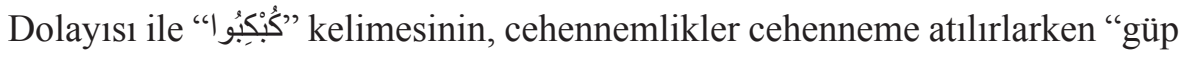
güp" şeklinde şiddetli seslerin de çıkacağını ifade ettiği söylenebilir.

Şu âyetlerde geçen " الجُبّ" kelimelerini de bu açıdan değerlendirmek mümkündür:

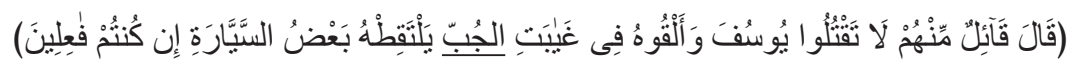

*“Onlardan biri, 'Yusuf'u öldürmeyin, eğer mutlaka yapacaksanız onu kuyunun dibine atın da geçen kervanlardan biri onu alsın (götürsün)' dedi."

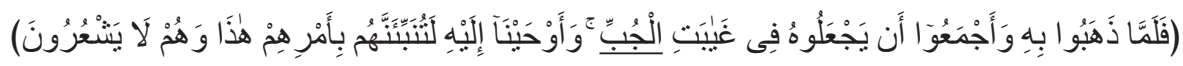

*“'Onu götürüp de kuyunun dibine atmaya ittifakla karar verdikleri zaman, biz Yusuf'a, 'andolsun ki sen onların bu işlerini onlar (işin) farkına varmadan, kendilerine haber vereceksin' diye vahyettik." ${ }^{57}$

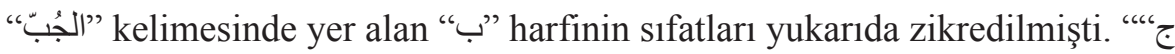
harfinin cehr, şiddet, qalqale, infitâh, istifâle, terkîk, zuhûr ve 1smât sıfatları vardir..$^{58}$

Kuyu anlamına gelen “"الجُبّ" kelimesindeki “ج" ve "ج" harfleri, s1fat ve mahreçlerine göre telaffuz edilirken "cup" şeklinde bir ses çıkarmaktadırlar. İşte bu ses, durgun bir suya bir cisim atıldığı zaman çıkan "cup" 59 sesine benzemektedir. Demek ki, zikredilen "الجُبّ" kelimesinin telaffuzu esnasında çıkan sesle, Yusuf[as]'1n atıldığı kuyunun içindeki suya düştüğü zaman çıkan ses birbirleriyle örtüşmektedir. Başka bir ifadeyle Yusuf[as]'ın kıssası anlatılırken kuyu anlamın-

55 Çağbayır, Yaşar, Ötüken Türkçe Sözlük, İstanbul, 2007, II, 1808 (“güp” mad.).

56 Yusuf (12), 10.

57 Yusuf (12), 15.

58 Karaçam, Kur'ân-ı Kerîm'in Faziletleri, s. 248. Bu sıfatlar yukarıda kısaca îzah edildiği için burada tekrar açıklanmayacaklardır.

59 Eren, Hasan ve arkadaşları, Türkçe Sözlük, Ankara, 1988, I, 264 (“cup” mad.); Çağbayır, Türkçe Sözlük, I, 837 (“cup” mad.). 
da bir kelime kullanmak gerekince, “الرَّسّ، النِّرْ ، القَلَيب gibi bu manaya gelen kelimeler arasından, telaffuz edilirken suya düşen cismin çıkardığı sese benzeyen bir ses veren "الجُبّب lafzı tercih edilmiştir.

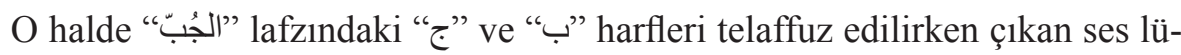
ğavî manaya, 'Yusuf[as]'ın kuyunun içindeki durgun suya yavaşça bırakılmayıp, -kuvvetli bir ses çıkaracak şekilde- aşağıya doğru şiddetle itilerek atıldığı' ek anlamını katmaktadır diyebiliriz.

$\mathrm{Bu}$ misallerden sonra şimdi Mustafa Sâdık er-Râfi'̂̀’nin şu özgün tespitini kaydederek çalışmamızı nihayete erdirelim:

"Kelimelerinin üç sesi vardır: Bunlardan birini ruh duyar, ikinci sesi akıl kavrar ve mananın ruha geçmesini sağlar, üçüncü ses ise his ve ruhu kapsar. İşte Kur'ân'daki i“câzın sırrı ve ruhu da budur." 60

\section{Sonuç}

Kur'ân, Yüce Allah'ın insanlığa gönderdiği en son ilahî metindir. Kur'ân'ın cevâmi 'u'l-kelim olduğu hemen her kesimin kabulüdür. Bu itibarla Kur'ân'1 anlamak için çeşitli açılardan çok sayıda araştırma ve inceleme yapılmış, ciltlerce tefsirler yazılmıştır. Ancak yapılan bu çalışmalarda, genellikle Kur'ân'ın edat ve kelimelerinin sözlük ve 1stılah anlamları üzerinde durulduğu görülmektedir.

Kur'ân'ın bir kısım kelimelerinin ifade ettikleri sözlük anlamları yanında, bu kelimeleri oluşturan bazı harflerin telaffuzu esnasında ortaya çıkan seslerin, söz konusu lüğavî manalara ek anlamlar kattıklarını söylemek mümkündür. Fonetik anlam yansımaları, Kur'ân'ın sahip olduğu bir başka mana zenginliği olarak "cevâmi'u'l-kelim" kapsamında kabul edilebilecek mahiyettedir. Dolayısı ile Kur'ân'ın bu yönüne de gereken önem atfedilmelidir.

İşte biz de bu küçük ebatlı makalede Kur'ân'ın bu özelliğine işaret etmeye çalıştık.

60 Keskioğlu, Osman, Son İlahî Kitap Kur'ân-ı Kerîm, Ankara, 1987, s. 23-24. 


\section{Kaynakça}

Muhammed Huseyn Ali es-Sağîr, es-Savtu'l-Lüğavî fi'l-Kur'ân, 1. bs., Beyrut, Dâru'l-Mü'errihi'l-Arabî, 1420/2000.

Aksu, Hüsamettin, "Hurûfîlik", Diyanet İslâm Ansiklopedisi (DİA), İstanbul, 1998.

Âlûsî, Ebu'l-Fazl Şihâbuddîn es-Seyyid Mahmûd, Rûhu'l-Me'ânî fî̀ Tefsîri'-Kur'âni'1-'Azîm ve's-Seb'il-Mesânî, Beyrut, Dâru İhyâ'i’t-Türasi'l-Arabi.

Askerî, Ebû Hilâl, el-Fürûk el-Lüğaviyye, tahqîq ve ta'lîq Muhammed İbrâhîm Selîm, Qâhira, Dâru'l-İlm ve's-Seqâfeti.

Ateş, Süleyman, İslâm'a İtirazlar ve Kur'ân-1 Kerîm'den Cevaplar, 4. bs., Ankara.

Buhârî, Muhammed b. İsmâ‘îl, Sahîhu’l-Buhârî, İstanbul, 1981.

Cezâ'irî, Nûruddîn b. Ni‘metillah el-Huseynî el-Mûsevî, Fürûqu'l-Lüğât, tahqîq Muhammed Razvânuddâye, Dımaşq.

Çağbayır, Yaşar, Ötüken Türkçe Sözlük, İstanbul, 2007.

Ebû Hayyân, Muhammed b. Yusuf, el-Bahru'l-Muhît, tahkik Âdil Ahmed Abdulmevcûd, Ali Muhammed Muavvaz, 1. bs., Beyrut, Dârul'1-Kütübi'l-İlmiyye.

Eren, Hasan ve arkadaşları, Türkçe Sözlük, Ankara, 1988.

Ğânim Kaddûrî el-Hamed, el-Medhal ilâ İlmi Esvâti'1- ‘Arabiyye, 1. bs., Ammân, Dâru Ammâr, 1425/2004.

el-Halîl b. Ahmed, Ebû 'Abdirrahmân el-Ferâhîdî, Kitâbu'l-'Ayn, tahqîq Mehdî el-Mahzûmî, İbrâhîm es-Sâmirâ'î, Beyrut, 1988.

İbn Manzûr, Muhammed b. Mükerrem b. 'Alî b. Ahmed el-Ensârî, Lisânu'l-‘Arab, Beyrut, Dâru Sâdır, 1990/1410.

Karaçam, İsmail, Kur'ân-1 Kerîm'in Faziletleri ve Okuma Kaideleri, İstanbul, Marmara Üniversitesi İlahiyat Fakültesi Yayınları.

Keskioğlu, Osman, Son İlahî Kitap Kur'ân-1 Kerîm, Ankara, 1987.

Kutub, Seyyid, et-Tasvîru'l-Fenniyyu fi'l-Qur'ân, Beyrut-Kâhire, Dâru'ş-Şurûq, 6. bs.-7. bs., 1400/1980-1402/1982.

Maverdî, Ebu'l-Hasen Ali b. Muhammed b. Habîb, en-Nüket ve'l-'Uyûn, ta 'lîq es-Seyyid b. Abdilmaqsûd b. Abdirrahîm, Beyrut, Dâru'l-Kütübi'l-İlmiyye - Mü'essesetü'l-Kütübi's-Sekâfiyye. 
Mustafa Müslim, Mebâhis fî İ‘câzi'l-Kur'ân, 1. bs., Cidde-Su'ûdiyye, Dâru'l-Menâra, 1408/1988.

Müslim, Ebû'l-Huseyn Müslim b. El-Haccâc, Sahîhu Müslim, İstanbul, 1981.

es-Safedî, Cemâluddîn Yûsuf b. Hilâl b. Ebi'l-Berekât, Keşfu'l-Esrâr ve Hetkü'l-Estâr, Nuru Osmaniye Kütüphanesi, numara, 416.

es-Şa'ravi, Muhammed Mütevelli, Mu'cizetü'l-Kur'ân, Ahbâru'l-Yevm, İdâretu'l-Kütübi ve'l-Mektebât.

Tetik, Necati, "Ses ve Anlam İlişkisi Bakımından Kur'ân ve Kırâat”, Kur'ân ve Dil (Dilbilim ve Hermenötik) Sempozyumu, 17-18 May1s, 2001.

Vehbe ez-Zühaylî, et-Tefsîru'l-Münîr fi'l-'Akîdeti ve'ş-Şerî‘ati ve'l-Menheci, 10. bs., Dımaşq, Dâru'l-Fikr, 1430/2009.

Yazır, Hamdi, Hak Dini Kur'ân Dili, İstanbul.

Yıldırım, Celal, İlmin Işı̆̆ında Asrın Kur’ân Tefsiri, İstanbul, 1991.

ez-Zebîdî, Muhibbuddîn Ebû'l-Fayz es-Seyyid Muhammed Murtaza, Tâcu'l-'Arûs, tahqîq Mustafa el-Hicâzî, Kuveyt, 1393/1973. 
